Alex G. Cuenca

Lyle L. Moldawer

\section{Myeloid-derived suppressor cells in sepsis: friend or foe?}

Received: 14 March 2012

Accepted: 1 April 2012

Published online: 3 May 2012

(C) Copyright jointly held by Springer and ESICM 2012

This editorial refers to the article available at: doi:10.1007/s00134-012-2574-4.

\section{A. G. Cuenca · L. L. Moldawer $(\square)$}

Department of Surgery, Shands Hospital, University of Florida

College of Medicine, Room 6116, 1600 SW Archer Rd,

Gainesville, FL 32610-0286, USA

e-mail: moldawer@surgery.ufl.edu

Tel.: +1-352-2650494

Fax: +1-352-2650676

Through improvements in supportive care measures over the last few decades, such as those guidelines based on the 'Surviving Sepsis Campaign' and early goal-directed therapy trials, we have been able to help most of our patients survive through the initial systemic inflammatory response period $[1,2]$. Unfortunately, a significant portion of patients still have protracted hospital courses and eventually succumb to late nosocomial infections [3]. These late sepsis-associated morbidities are thought to be related to global host immunosuppression.

Though this is not a newly described phenomenon, there is still considerable controversy as to how this immunosuppression occurs [4,5]. Many investigators, including ourselves, have demonstrated extensive lymphocyte and antigen-presenting cell apoptosis in secondary lymphoid organs [6-8]. In addition, the presence of $\mathrm{T}$ cell exhaustion, as well as the expansion of regulatory $\mathrm{T}$ cell populations, has been described in both septic humans and mice [9-11]. Also, we and others have demonstrated that the expansion of an immature myeloid population, known as myeloid-derived suppressor cells
(MDSCs), occurs following sepsis [12, 13]. However, the question remains, which of these phenomena, if any, contribute to or are critical for persistent inflammation and the late global immunosuppression that leads to protein wasting and the increased prevalence of nosocomial infections in our septic patients?

Despite the large body of data that exists looking at each one of these cell populations, there is no consensus, and the answer is more than likely multifactorial. In addition, though the presence of these cell populations may be associated with late mortality and morbidity in sepsis, the role they play in the early response to sepsis may be critical to mitigate the deleterious effects of the systemic inflammatory response syndrome. This is more than likely true of the MDSC, which despite its wellpublicized deleterious effects on tumor immune surveillance, may actually be a critically important component of the innate immune response following septic insult.

Originally described in the cancer literature, it is now clear that MDSCs, roughly characterized as CD11 ${ }^{+} \mathrm{Gr}-1^{+}$ cells, arise in many pathologic processes including autoimmunity and burn/trauma injury [12]. MDSCs are purported to suppress immunosurveillance during tumorigenesis, through the production of arginase, reactive oxygen species (ROS), and/or inducible nitric oxide, though their role in sepsis is less clear. Delano et al. [12] originally described a dramatic expansion of MDSCs following murine polymicrobial sepsis and demonstrated that these cells may indeed suppress adaptive immune responses. However, since then, several groups, including ourselves, have demonstrated that this expansion of MDSCs during sepsis may actually be protective $[13,15]$. The current report in Intensive Care Medicine by Derive et al. [14] explores this subject further.

Though many investigators have ascribed one standard phenotype to MDSCs, Derive and colleagues demonstrate a phenotypic change in the $\mathrm{CD} 11 \mathrm{~b}^{+} \mathrm{Gr}-1^{+}$cells isolated at day 3 following sepsis compared to the $\mathrm{CD} 11 \mathrm{~b}^{+} \mathrm{Gr}-1^{+}$ 
isolated 10 days after polymicrobial sepsis. We have also shown such a phenotypic change in neutrophils $\left(\mathrm{CD} 11 \mathrm{~b}^{+} \mathrm{Gr}-1^{+}\right.$cells) from the bronchiolar lavages of septic mice and shown that neutrophils isolated at day 3 following sepsis produced significantly less ROS compared to neutrophils isolated 7 days following sepsis and were less mature [15]. Derive et al. demonstrate a similar decrease in ROS in response to IL-6 at day 3 but an increase in ROS production in MDSCs isolated from mice 10 days post sepsis. They also show that at day 3 MDSCs produce significantly less cytokines in response to LPS stimulation than MDSCs isolated from mice at day 10 post sepsis. These data together with gene expression array data from MDSCs isolated from mice either at day 3 versus day 10 following sepsis suggest that $C D 11 b^{+} \mathrm{Gr}-1^{+}$ cells isolated 3 days following sepsis expand but are not capable of being activated until days 7-10.

In addition, the authors also demonstrate that MDSCs isolated from mice at day 10 following sepsis are able to attenuate inflammatory cytokines locally, facilitate bacterial clearance, and overall improve survival to polymicrobial sepsis. These data are similar to the findings of Sander et al. [13], who showed that the MDSCs that expand following septic insult suppress inflammatory responses and may indeed be protective. However, taken together with the data that demonstrate that MDSCs suppress $T$ cell responses, it is easy to see how the robust expansion of these cells that occur following sepsis may also contribute to adaptive immunosuppression.

Unfortunately, these data also exemplify the difficulty in defining a discrete novel population in the MDSC from traditional innate immune effector cells, such as the neutrophil, using only the cell surface markers, $\mathrm{CD} 11 \mathrm{~b}^{+} \mathrm{Gr}-$ $1^{+}$. In the adult, $\mathrm{CD} 11 \mathrm{~b}^{+} \mathrm{Gr}-1^{+}$can encompass neutrophil, monocyte, and MDSC populations, which are clearly heterogenous, comprised of both granulocytic and monocytic subsets [16]. The authors do demonstrate that these MDSCs can suppress adaptive immune responses, which is one of the defining characteristics of the MDSC; but again, are the authors looking at the MDSC or the more mature neutrophil? Is there a difference between these two cell populations or do the neutrophils that expand following the initial 'left' shift that typically follows severe infection represent a compartment of these MDSCs? More than likely, as the data the authors and other investigators have suggested, the MDSC and the phenotypic changes that occur following sepsis are part of the primary myeloid compartment reconstitution that occurs following infection, otherwise known as emergency myelopoiesis [17]. As 'MDSCs' emerge from the bone marrow in an attempt to localize and clear the infectious insult, they represent a continuum from immature to mature activated innate immune effector cells that are, at least in the mouse, protective to the initial septic hit.

However, is the absence of activated MDSCs in some patients following sepsis the reason why our patients subsequently succumb to nosocomial infection? Is it the expansion of MDSCs in the host following sepsis that leads to global adaptive immune suppression and secondary infection in the sepsis patient? The answer is unknown, as the corollary for the MDSC in human sepsis has yet to be identified. Once this has been established, more work will be needed to understand clearly what their role is in our critically ill patient populations and whether or not the MDSC is truly the friend or the foe. More than likely, it will be both.

Acknowledgments Supported in part by grants R01 GM-40586-22 and R01 GM-81923-03 from the National Institute of General Medical Sciences. AGC was supported by a T32 training grant in burns and trauma (T32 GM-08721-11). AGC was also supported by an individual NRSA award (F32 GM-093665-01) from the National Institute of General Medical Sciences.

\section{References}

1. Dellinger RP, Carlet JM, Masur H, Gerlach H, Calandra T, Cohen J, GeaBanacloche J, Keh D, Marshall JC, Parker MM, Ramsay G, Zimmerman JL, Vincent JL, Levy MM, Surviving Sepsis Campaign Management Guidelines C (2004) Surviving sepsis campaign guidelines for management of severe sepsis and septic shock. Crit Care Med 32:858-873

2. Rivers E, Nguyen B, Havstad S, Ressler J, Muzzin A, Knoblich B, Peterson E, Tomlanovich M, Early Goal-Directed Therapy Collaborative G (2001) Early goal-directed therapy in the treatment of severe sepsis and septic shock. N Engl J Med 345:1368-1377
3. Pronovost P, Needham D, Berenholtz S, Sinopoli D, Chu H, Cosgrove S, Sexton B, Hyzy R, Welsh R, Roth G, Bander J, Kepros J, Goeschel C (2006) An intervention to decrease catheter-related bloodstream infections in the ICU. N Engl J Med 355:2725-2732

4. Cuenca AG, Delano MJ, Kelly-Scumpia KM, Moreno C, Scumpia PO, Laface DM, Heyworth PG, Efron PA, Moldawer LL (2010) A paradoxical role for myeloid derived suppressor cells in sepsis and trauma. Mol Med $17: 281-292$

5. Hotchkiss RS, Opal S (2010)

Immunotherapy for sepsis-a new approach against an ancient foe. N Engl J Med 363:87-89
6. Hotchkiss RS, Swanson PE, Cobb JP, Jacobson A, Buchman TG, Karl IE (1997) Apoptosis in lymphoid and parenchymal cells during sepsis: findings in normal and T- and B-celldeficient mice. Crit Care Med 25:1298-1307

7. Hiramatsu M, Hotchkiss RS, Karl IE, Buchman TG (1997) Cecal ligation and puncture (CLP) induces apoptosis in thymus, spleen, lung, and gut by an endotoxin and TNF-independent pathway. Shock 7:247-253 
8. Efron PA, Martins A, Minnich D, Tinsley K, Ungaro R, Bahjat FR, Hotchkiss R, Clare-Salzler M, Moldawer LL (2004) Characterization of the systemic loss of dendritic cells in murine lymph nodes during polymicrobial sepsis. J Immunol 173:3035-3043

9. Boomer JS, To K, Chang KC, Takasu O, Osborne DF, Walton AH, Bricker TL, Jarman SD 2nd, Kreisel D, Krupnick AS, Srivastava A, Swanson PE, Green JM, Hotchkiss RS (2011) Immunosuppression in patients who die of sepsis and multiple organ failure. JAMA 306:2594-2605

10. Venet F, Chung CS, Kherouf H, Geeraert A, Malcus C, Poitevin F, Bohe J, Lepape A, Ayala A, Monneret G (2009) Increased circulating regulatory T cells $(\mathrm{CD} 4(+) \mathrm{CD} 25(+) \mathrm{CD} 127(-))$ contribute to lymphocyte anergy in septic shock patients. Intensive Care Med 35:678-686

11. Venet F, Chung CS, Monneret G, Huang X, Horner B, Garber M, Ayala A (2008) Regulatory T cell populations in sepsis and trauma. J Leukoc Biol 83:523-535
12. Delano MJ, Scumpia PO, Weinstein JS, Coco D, Nagaraj S, Kelly-Scumpia KM, O'Malley KA, Wynn JL,

Antonenko S, Al-Quran SZ, Swan R, Chung CS, Atkinson MA, Ramphal R, Gabrilovich DI, Reeves WH, Ayala A, Phillips J, Laface D, Heyworth PG, Clare-Salzler M, Moldawer LL (2007) MyD88-dependent expansion of an immature GR-1(+)CD11b(+) population induces $\mathrm{T}$ cell suppression and Th2 polarization in sepsis. J Exp Med 204:1463-1474

13. Sander LE, Sackett SD, Dierssen U, Beraza N, Linke RP, Muller M, Blander JM, Tacke F, Trautwein C (2010) Hepatic acute-phase proteins control innate immune responses during infection by promoting myeloid-derived suppressor cell function. J Exp Med 207:1453-1464

14. Derive M, Bouazza Y, Alauzet C, Gibot S (2012) Myeloid-derived suppressor cells control microbial sepsis. Intensive Care Med. doi: 10.1007/s00134-012-2574-4
15. Delano MJ, Thayer T, Gabrilovich S, Kelly-Scumpia KM, Winfield RD, Scumpia PO, Cuenca AG, Warner E, Wallet SM, Wallet MA, O'Malley KA, Ramphal R, Clare-Salzer M, Efron PA, Mathews CE, Moldawer LL (2010) Sepsis induces early alterations in innate immunity that impact mortality to secondary infection. J Immunol 186:195-202

16. Gabrilovich DI, Nagaraj S (2009) Myeloid-derived suppressor cells as regulators of the immune system. Nat Rev Immunol 9:162-174

17. Cuenca AG, Delano MJ, KellyScumpia KM, Moreno C, Scumpia PO, Laface DM, Heyworth PG, Efron PA, Moldawer LL (2011) A paradoxical role for myeloid-derived suppressor cells in sepsis and trauma. Mol Med 17:281-292 